\title{
IDENTIFIKASI FUNGSI BAHASA YANG BERBASISKAN KEARIFAN LOKAL BALI PADA MATERI PEMBELAJARAN BAHASA INGGRIS PERHOTELAN BIDANG TATA HIDANG
}

\author{
Ni Made Ayu Sulasmini ${ }^{1}$, Nyoman Gede Astina ${ }^{2}$ \\ ${ }^{I}$ Manajemen Kepariwisataan, STPBI, Denpasar, ayu.sulasmini@stpbi.ac.id \\ ${ }^{2}$ Manajemen Perhotelan, STPBI, astina.nyomangede@gmail.com
}

\begin{abstract}
:
The values of local wisdom that are reflected in the service influences the satisfaction of tourists (Astina, 2017). Local wisdom is displayed in the daily life of the people, including the use of local languages. Bali as a cultural community certainly has that identity of language, in addition to religious and political systems, customs, tools, clothing, buildings and artwork. This study aims to identify the use of Balinese Language within the restaurant sequence of service. Kuta and Sanur are the sampling setting since the two are indicators of Tourism destination. The use of Balinese language expressions were also recognized from the teaching and learning in the hospitality classroom to see the gap. The study displayed the use of Balinese Language 'matur suksma'(=thank you) in the sequence of service and is a subject of English Language material development in the area of food and beverage service.
\end{abstract}

Keywords: Service, Local Wisdom, Language Function, Food and Beverage Service

\section{PENDAHULUAN}

Layanan memberikan kontribusi terhadap pengalaman wisatawan. Beberapa penelitian telah menunjukan signifikansi layanan yang bermuara pada kepuasan wisatawan. World Tourism Organization (WTO), 2003 telah menetapkan standar kualitas produk atau layanan dalam bidang pariwisata, (Tourism Service QualityTourServQual), diantaranya (1) orisinalitas (authenticity), dan (2) harmoni (harmony). Faktor orisinalitas (authenticity) dan harmoni (harmony) merupakan faktor yang terkait dengan budaya dan kearifan lokal.

Pariwisata yang berkualitas menurut WTO adalah pariwisata yang tidak merusak budaya dan kearifan lokal yang ada pada destinasi, tetapi pariwisata dapat melestarikan keberadaan budaya dan kearifan lokal dengan menjaga hubungan yang harmonis antara wisatawan dan penduduk lokal, serta lingkungan sekitarnya. Dengan demikian layanan yang berkualitas dalam bidang pariwisata adalah layanan yang memperhatikan keberadaan unsur-unsur yang terkait dengan budaya dan kearifan lokal.

Sebagai suatu interaksi, segala sesuatu yang berhubungan dengan proses interaksi tersebut, diasumsikan berperan dalam memberikan pengalaman. Bahasa salah satunya, yang merupakan pengantar interaksi, memberikan kesan awal di dalam layanan. Khususnya pada area layanan di restoran, pemilihan fungsi-fungsi bahasa akan sangat berpengaruh pada kesan tersebut. 


\section{National Conference of Creative Industry: \\ Sustainable Tourism Industry for Economic Development}

Universitas Bunda Mulia, Jakarta, 5-6 September 2018 e-ISSN No: 2622-7436

Kearifan lokal Bali yang mempengaruhi pelayanan, seperti halnya dalam penelitian Astina (2017) meliputi: jemet, tresna, asih dan bakti. Jemet adalah karakter orang Bali yang bersedia untuk bekerja dengan cepat berdasarkan kreatifitas dan percaya diri. Tresna dimaknai sebagai sikap orang Bali yang mampu menghormati orang lain. Karyawan yang tresna adalah karyawan yang bersikap ramah, selalu menunjukkan senyuman yang ceria sebagai ciri khas orang Bali, bersikap sopan, menghormati kondisi tamu, dan karyawan yang tidak terlalu sibuk dalam melayani tamu. Asih diartikan sebagai sifat orang Bali yang menyayangi sesama makhluk. Rasa sayang ini tercermin dalam sikap dan perilaku orang Bali yang memberikan sentuhan kasih sayang kepada semua makhluk di dunia. Karyawan yang asih adalah karyawan yang dapat memberikan perhatian secara personal kepada setiap pelanggan, tidak bersikap kasar, dan selalu siap memberikan bantuan. Bhakti merupakan sikap orang Bali yang rendah hati disertai tindakan yang dapat meyakinkan pelanggan. Karyawan tersebut bersikap rendah hati dalam melayani tamu hotel, tidak memiliki rasa takut ketika berinteraksi dengan tamu hotel, karyawan dapat bertindak secara meyakinkan dalam memenuhi kebutuhan tamu hotel, dan karyawan memiliki keprihatinan sehingga berhati-hati atas tindakan dan tutur bahasanya.

Bahasa merupakan media komunikasi yang dapat memfasilitasi interaksi. Fungsi bahasa mengacu pada tujuan bahasa dalam berkomunikasi. Sementara itu, fungsi bahasa di dalam layanan di restoran mengikuti sequense of service atau tahapan layanan. Di setiap tahapannya, terdapat penggunaan fungsi bahasa oleh pelayan yang disesuaikan dengan kebutuhan setiap tahapan layanan tersebut. Penelitian ini akan memetakan fungsi bahasa tersebut agar mencerminkan kearifan lokal Bali jemet, tresna, asih dan bakti sehingga memberikan pengalaman yang lebih maksimal kepada wisatawan untuk berinteraksi dengan budaya lokal.

Berdasarkan latar belakang yang telah dipaparkan, maka penelitian ini bertujuan untuk mengidentifikasi fungsi bahasa yang berbasiskan kearifan lokal pada materi pembelajaran Bahasa Inggris Perhotelan Bidang Tata Hidang. Hasil penelitian ini dapat dijadikan acuan di dalam pengembangan materi bahasa Inggris yang mencerminkan kearifan lokal Bali, khususnya di bidang Tata Hidang.

\section{TINJAUAN PUSTAKA}

\section{Layanan}

Menurut Lovelock dan Wright (2005), layanan adalah tindakan atau kinerja yang menciptakan manfaat bagi pelanggan dengan mewujudkan perubahan yang diinginkan dalam diri penerima layanan. Menurut Kotler dan Armstrong (2003), layanan adalah berbagai kegiatan atau manfaat yang dapat ditawarkan oleh satu pihak kepada pihak lain yang pada dasarnya tidak berwujud, dan tidak menghasilkan perpindahan kepemilikan. Kedua pengertian tersebut menunjukan bahwa layanan melibatkan interaksi dari satu pihak ke pihak lain dan memberikan perubahan dalam diri penerima layanan.

Layananbiasanyadirasakansecarasubjektif oleh pelanggan dengan melibatkan berbagai macam ekspresi yang terkait dengan pengalaman, kepercayaan, perasaan, dan kenyaman pelanggan. Pengertian ini menunjukan peran layanan yang krusial di dalam memenangkan pengalaman, kepercayaan, perasaan serta kenyamanan pelanggan. Segala aspek yang menjadi karakterisktik dasar pelayanan hendaknya diperhatikan dengan detail. Menurut Gronroos (1998), layanan memiliki empat karakteristik dasar, yaitu: (1) 


\section{National Conference of Creative Industry: \\ Sustainable Tourism Industry for Economic Development}

Universitas Bunda Mulia, Jakarta, 5-6 September 2018 e-ISSN No: 2622-7436

bersifat tidak berwujud (intangibles), (2) merupakan serangkaian aktivitas, (3) proses produksi dan konsumsi dilakukan secara bersamaan, dan (4) adanya partisipasi konsumen dalam proses produksi. Sedangkan menurut Kotler dan Armstrong (2003) layanan memiliki karakteristik yang terdiri atas: (1) tidak berwujud, (2) tidak terpisahkan (inseparable), (3) berubah-ubah, dan (4) tidak tahan lama.

\section{Kearifan Lokal Bali}

Karakteristik setiap orang sangat dipengaruhi oleh lingkungan di mana mereka hidup dan berkembang. Demikian pula halnya dengan karakteristik orang Bali tidak hanya dipengaruhi oleh lingkungan sosialnya, tetapi juga dipengaruhi oleh lingkungan spiritual yang telah menjadi kearifan lokal yang sangat kuat dalam membentuk karakteristik orang Bali seutuhnya.

Kearifan lokal (local genius/local wisdom) merupakan pengetahuan lokal yang tercipta dari hasil adaptasi suatu komunitas yang berasal dari pengalaman hidup yang dikomunikasikan dari generasi ke generasi (Restu Gunawan, 2008 dalam Wisnumurti, 2010). Di Bali, proses regenerasi kearifan lokal ini biasanya dapat dilakukan melalui tradisi lisan (cerita rakyat) dan karya-karya sastra, seperti babad, suluk, tembang, hikayat, lontar, dan lain-lain. Seluruh nilai-nilai kerafian lokal tersebut telah memberikan makna bagi kehidupan sosial pada masyarakat Bali, dan menjadi rujukan serta bahan acuan dalam menjaga dan menciptakahn relasi sosial yang harmonis. Sistem pengetahuan lokal ini dipahami sebagai sistem pengetahuan yang dinamis dan berkembang terus secara kontekstual sejalan dengan tuntutan kebutuhan manusia yang semakin heterogen dan kompleks. Nilai kearifan lokal akan memiliki makna apabila tetap menjadi rujukan dalam mengatasi setiap dinamika kehidupan sosial, lebih-lebih lagi dalam menyikapi berbagai perbedaan yang rentan menimbulkan konflik. Nilai-nilai kearifan lokal yang bersumber dari ajaran Agama Hindu telah menjadi rujukan dan bahan acuan dalam menjaga dan menciptakan relasi sosial yang harmonis pada masyarakat Bali.

Dalam konteks layanan, penelitian Astina (2017) menemukan bahwa layanan yang berbasiskan kearifan lokal Bali mempengaruhi kepuasan dan loyalitas wisatawan. Penelitian ini diawali dengan Focus Grup Discussion dengan menghadirkan linguists, budayawan, pemuka agama, organisasi, serta peneliti budaya Bali yang pada akhirnya menemukan 4 (empat) nilai kearifan lokal Bali yang berpengaruh positif terhadap kualitas layanan dan minat perilaku loyal wisatawan. Adapun keempat kearifan lokal tersebut, yang disebut sebagai catur sewaka, terdiri dari karakter jemet, tresna, asih, dan bakti.

Jemet adalah karakter orang Bali yang bersedia untuk bekerja dengan cepat berdasarkan kreatifitas dan percaya diri. Orang Bali jika diberikan kesempatan untuk mengembangkan kreativitasnya dapat menghasilkan karya yang sangat memuaskan, bahkan wisatawan mancanegara sangat kagum dengan berbagai karya yang memiliki nilai seni hasil kreativitas dari karyawan hotel yang memiliki karakter jemet. Dengan demikian dimensi jemet dalam konsep penelitian ini dapat merefleksikan kualitas layanan karyawan hotel yang cepat, kreatif, serta percaya diri. Karyawan yangjemet adalah karyawan yang dapat menunjukkan kecepatan dalam layanan di hotel, kreatifitasnya tinggi dalam melayani tamu hotel, dan percaya diri dalam berinteraksi dengan tamu.

Tresna dimaknai sebagai sikap orang Bali yang mampu menghormati orang lain. Kemampuan orang Bali dalam menunjukkan sikap menghormati orang lain ini menyebabkan Bali terkenal dengan keramah tamahannya. Karyawan yangtresna adalah 


\section{National Conference of Creative Industry: \\ Sustainable Tourism Industry for Economic Development}

Universitas Bunda Mulia, Jakarta, 5-6 September 2018 e-ISSN No: 2622-7436

karyawan yang bersikap ramah, selalu menunjukkan senyuman yang ceria sebagai ciri khas orang Bali, bersipan sopan, menghormati kondisi tamu, dan karyawan yang tidak terlalu sibuk dalam melayani tamu.

Asih diartikan sebagai sifat orang Bali yang menyayangi sesama makhluk. Rasa sayang ini tercermin dalam sikap dan perilaku orang Bali yang memberikan sentuhan kasih sayang kepada semua makhluk di dunia. Upacara suci atau yadnya yang diselenggarakan dalam kehidupan sehari-hari masyarakat Bali tidak hanya ditujukan kepada Tuhan dan manusia saja, tetapi orang Bali juga melakukan yadnya untuk hewan dan tumbuhan. Perilaku ini mencerminkan bahwa orang Bali memiliki sifat kasih sayang yang tinggi. Karyawan yangasih adalah karyawan yang dapat memberikan perhatian secara personal kepada setiap pelanggan, tidak bersikap kasar, dan selalu siap memberikan bantuan.

Bhakti merupakan sikap orang Bali yang rendah hati disertai tindakan yang dapat meyakinkan pelanggan. Persepsi wisatawan mancanegara terhadap karyawan hotel yang bhakti adalah karyawan tersebut bersikap rendah hati dalam melayani tamu hotel, tidak memiliki rasa takut ketika berinteraksi dengan tamu hotel, karyawan dapat bertindak secara meyakinkan dalam memenuhi kebutuhan tamu hotel, dan karyawan memiliki keprihatinan sehingga berhati-hati atas tindakannya.

\section{Fungsi Bahasa}

Halliday dan Hasan (1985) mendefinisikan fungsi bahasa sebagai penggunaan bahasa dengan cara bertutur dan menulis serta membaca dan mendengar untuk mencapai sasaran dan tujuan. Brown (2007) menambahkan bahwa fungsi bahasa pada dasarnya adalah tujuan yang dicapai dengan bahasa, misalnya menyatakan, meminta, menanggapi, memberi salam, mengucapkan kata perpisahan, dan sebagainya. Adapun fungsi-fungsi bahasa dalam bahasa Inggris diantaranya: Compare and contrast, persuasion, asking questions, expressing likes and dislikes, cause and effect, summarizing, sequencing, predicting, agreeing/disagreeing, dan greeting people/introduction.

Fungsi-fungsi bahasa Inggris di restoran terlihat dengan digunakannya ekspresi bahasa oleh karyawan restoran dan tamu untuk mencapai tujuan komunikasi, khususnya mengenai layanan makanan dan minuman di restoran. Selanjutnya, di dalam ranah restoran, fungsi-fungsi bahasa yang biasa digunakan mengikuti sequence of service. Sequence of service pada aplikasi restoran diantaranya: greeting and welcoming the guest, escorting the guest, seating the guest, unfolding the napkin, pouring the ice water, introducing and explaining the menu, serving bread and butter, serving food and clearing up dirty dishes, serta farwelling the guest.

\section{Tata Hidang}

Tata Hidang merupakan istilah yang dipakai dalam bidang perhotelan. Tata hidang menekankan kepada cara menyusun serta memperindah makanan dan minuman yang disajikan kepada tamu atau konsumen di restoran.

Dalam penyajian makanan dan minuman terdapat tiga tahapan yang harus diperhatikan (Siegel, 2000 dalam Lestari, 2017). Tiga tahapan tersebut diuraikan sebagai berikut. 


\section{National Conference of Creative Industry: \\ Sustainable Tourism Industry for Economic Development}

Universitas Bunda Mulia, Jakarta, 5-6 September 2018 e-ISSN No: 2622-7436

1) Persiapan (Mise en place): Persiapan yang baik (misalnya peralatan makan, posisi meja dan kursi, dan sebagainya) tentunya akan berdampak pada penyajian yang baik pula.

2) Pelayanan terhadap tamu: Pramusaji harus senantiasa berkonsentrasi dalam melayani setiap tamu karena kepuasan tamu terletak pada pelayanan yang maksimal.

3) Penjualan: Pelayanan yang memuaskan terhadap tamu juga merupakan sarana penjualan produk restoran, yakni makanan dan minuman yang ditawarkan, sehingga dapat meningkatkan pendapatan atas penjualan. Oleh karena itu, pengetahuan yang baik mengenai penjualan juga merupakan hal yang penting bagi seorang pramusaji.

Ketika seorang pramusaji melayani tamu di restoran, ia harus mengikuti beberapa prosedur kerja yang disebut sebagai sequence of service. Secara umum, prosedur pelayanan tamu di restoran dapat diuraikan sebagai berikut (Siegel, 2010, dalam Lestari 2017).

(1) Welcoming guests (menyambut tamu)

(2) Seating the guests (mengarahkan tamu ke mejanya)

(3) Checking comfort and seating arrangement (memastikan kenyamanan tamu)

(4) Serving water (menyajikan air minum)

(5) Presenting menu (memberikan menu)

(6) Taking order (mencatat pesanan makanan dan minuman)

(7) Recommending (merekomendasikan produk)

(8) Repeating orders (mengulangi pesanan)

(9) Presenting food and drinks (menghidangkan makanan dan minuman)

(10) Checking guests'satisfaction (memastikan kepuasan tamu)

(11) Offering dessert (menawarkan hidangan penutup)

(12) Clearing and crumbing (membersihkan meja dari piring kotor)

(13) Presenting thebill (memberikan tagihan)

(14) Thanking the guests and farewell (mengucapkan terima kasih dan salam penutup)

\section{METODE PENELITIAN}

Penelitian ini adalah penelitian qualitatif. Data diperoleh dari hasil observasi direstoran dan pada praktek pengajaran Bahasa Inggris Tata Hidang di kelas, wawancara dengan otoritas restoran serta dokumentasi. Hasil observasi dan wawancara yang dilakukan di restoran kemudian dibandingkan dengan hasil observasi pengajaran Bahasa Inggris Tata Hidang di kelas, guna merekomendasikan lebih lanjut fungsi Bahasa Bali yang ditemukan pada area layanan di restoran. Observasi dan wawancara dilakukan pada restoran di area Sanur mengingat sanur merupakan destinasi yang sangat populer dan restoran dan hotel di sanur umumnya dimiliki dan dikelola oleh masyarakat lokal Bali. 


\section{National Conference of Creative Industry: \\ Sustainable Tourism Industry for Economic Development}

Universitas Bunda Mulia, Jakarta, 5-6 September 2018

e-ISSN No: 2622-7436

\section{HASIL PENELITIAN DAN PEMBAHASAN}

\section{Identifikasi penggunaan Bahasa Bali dalam Pelayanan oleh Pramusaji Restoran}

Nilai - nilai kearifan lokal yang tercermin di dalam pelayanan memiliki pengaruh terhadap kepuasan wisatawan (Astina, 2017). Nilai kearifan lokal tersebut tertuang dalam kehidupan masyarakat sehari-hari, tidak terkecuali dari segi pengunaan Bahasa daerah.

Bahasa sebagai salah satu identitas suatu budaya merupakan salah satu aspek kearifan lokal sebagai identitas penciri suatu komunitas. Bali sebagai suatu komunitas budaya tentunya memiliki identitas tersebut, selain sistem agama dan politik, adat istiadat, perkakas, pakaian, bangunan dan karya seni.

Bahasa Bali dituturkan di daerah Bali, Lombok bagian barat serta di beberapa di kawasan ujung timur pulau Jawa. Bahasa Bali lazim digunakan dalam kegiatan formal adat, rangkaian upacara peminangan wanita ataupun ketika bersosialisasi antar rekan sejawat. Sesuai dengan tingkat formalitas serta penutur bahasanya, Bahasa Bali memiliki 3 (tiga) tingkatan yakni Bahasa Bali Alus, Bahasa Bali Madya, dan Bahasa Bali Kasar. Bahasa Bali Alus digunakan dalam situasi adat formal, seperti halnya pertemuan adat, acara peminangan dan sejenisnya. Bahasa Bali Alus dituturkan oleh masyarakat Bali dengan kasta tertinggi. Bahasa Bali Madya digunakan di tingkat masyarakat menengah sementara Bahasa Bali Kasar digunakan oleh kelas rendah misalnya kaum sudra ataupun antara yang berkasta dengan orang-orang yang bekerja untuknya.

Identitas budaya pada masyarakat tentunya akan melalui dinamisme asimilasi (pembauran dan membentuk budaya baru) serta akulturasi (menerima budaya asing tanpa menghilangkan kebudayaan sendiri).

Tidak terkecuali pada dinamisme masyarakat Sanur yang merupakan salah satu tujuan wisata nusantara dan asing. Sanur merupakan destinasi yang selalu ramai dikunjungi oleh wisatawan nusantara dan asing. Destinasi sanur menawarkan suasana yang lebih tenang dibandingkan dengan Kuta serta jarak tempuh yang lebih pendek dibandingkan pantai lainnya dari arah pusat kota (Denpasar). Sepanjang garis pantai Sanur. Terdapat beberapa pantai diantaranya, Merta Sari Sanur, Semawang Sanur, Batu Jimbar Sanur, Karang Sanur, Segara Ayu Sanur, dan Pantai Matahari Terbit Sanur. Mengingat kepopulerannya, tentunya berbagai macam budaya akan berinteraksi di daerah ini yang cenderung berimbas pada budaya lokal masyarakat setempat, termasuk di dalamnya penggunaan Bahasa di dalam berkomunikasi. Selain Sanur, Kuta juga merupakan destinasi wajib bagi tidak hanya wisatawan asing tetapi juga wisatawan nusantara, sehingga interaksi yang kaya juga dapat ditemukan di areal ini.

\section{Penggunaan Bahasa Bali dalam Langkah-Langkah Pelayanan di Restoran}

Pada area pelayanan di restoran Sanur, penggunaan Bahasa Inggris merupakan suatu hal yang lumrah seperti halnya pada akomodasi lainnya yang disediakan khusus untuk wisatawan (Spa, Hotel, Trasportasi, dan sebagainya). Bahasa Inggris merupakan standar Bahasa yang dibakukan dalam standar operating procedure (SOP).

Langkah-langkah pelayanan (sequence of service) yang dilakukan meliputi welcoming the guest (menyambut tamu), seating the guest (mengarahkan tamu ke meja), checking comfort and seating arrangement (memastikan kenyamanan posisi duduk tamu), serving water (menyajikan air minum), presenting menu (memberikan menu), taking order (mencatat pesanan tamu), recommending (menyarankan 


\section{National Conference of Creative Industry: \\ Sustainable Tourism Industry for Economic Development}

Universitas Bunda Mulia, Jakarta, 5-6 September 2018 e-ISSN No: 2622-7436

produk/makanan/minuman), repeating orders (mengulangi pesanan), presenting food and drinks (menghidangkan makanan dan minuman), checking the guest's satisfaction (memastikan kepuasan tamu), offering dessert (menawarkan Hidang penutup), clearing and crumbing (membersihkan meja dan piring kotor) presenting the bill (memberikan tagihan), serta thanking the guest and farewell (mengucapkan salam perpisahan). Terdapat beberapa langkah pelayanan yang tidak dilakukan seperti halnya serving water sebelumpresenting the menu di beberapa restoran di daerah Sanur.

Penggunaan Bahasa Bali tidak terdapat pada keseluruhan langkah-langkah tersebut, jika mengacu pada SOP yang disusun oleh manajemen. Tetapi terlihat visual gerak tubuh (body language) yang dilakukan dengan mencakupkan tangan di dada sebelum mengucapakan salam sesuai waktu dalam bahasa Inggris (Good Morning, Good Afternoon, dsb).

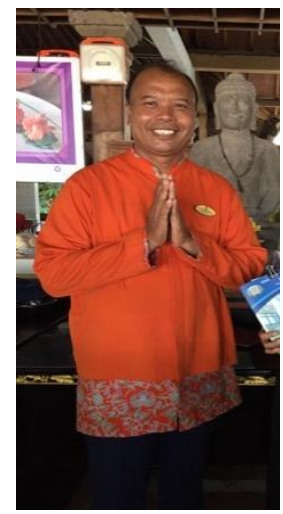

Gambarl : ilustrasi cakupan tangan ketika mengucapkan salam

Cakupan tangan dengan posisi kedua tangan di dada tersebut, dilakukan bersamaan dengan sapaan selamat datang di restoran. Cakupan tangan tersebut menimbulkan rasa keingintahuan pengunjung untuk menanyakan lebih lanjut apa makna gerakan tersebut. Pengunjung restoran seringkali berlatih melakukan gerakan tersebut. Bentuk komunikasi ini dapat menciptakan interaksi yang lebih mendalam antara pramusaji dengan pengunjung restoran.

Cakupan tangan pada keseharian masyarakat Bali merupakan suatu ekspresi gerak yang dilakukan dengan cakupan kedua tangan di dada, masing-masing jari tangan kanan dan tangan kiri bertemu. Gerakan tangan ini, ada kalanya dibarengi dengan posisi badan yang sedikit membungkuk guna menunjukan rasa hormat serta senyuman yang tulus. Masyarakat Bali pada umumnya jika bertemu dalam konteks adat akan melakukan gerakan ini sambil mengucapakan salam 'Om Swastyastu' (salam yang lazim diucapkan oleh umat hindu ketika bertemu).

Dalam agama Hindu sembahyang merupakan wujud nyata kegiatan beragama dengan tujuan untuk menghormati, menyerahkan diri, serta menghamba kepada Hyang Widhi Wasa (Tuhan Yang Maha Esa) ataupun yang disucikan. Diarahkan agar sikap badan yang dilakukan ketika sembahyang mengikuti ketentuan dari PHDI (Parisadha Hindu Dharma Indonesia). Adapun sikap tangan dalam melakukan sembahyang, seperti tercantum dalam buku Upadesa (1968), dibedakan berdasarkan kepada siapa sembah tersebut dilakukan. Posisi tangan Kehadapan Sang Hyang Widhi, cakupan tangan diletakkan di atas dahi hingga ujung jari ada diatas ubun-ubun. Sedangkan posisi tangan untuk sembah kehadapan para Dewa (Dewata), ujung jari-jari tangan di atas, di antara 


\section{National Conference of Creative Industry: \\ Sustainable Tourism Industry for Economic Development}

Universitas Bunda Mulia, Jakarta, 5-6 September 2018 e-ISSN No: 2622-7436

kening. Selanjutnya, sembah yang diperuntukan kepada Pitara (roh leluhur), ujung jarijari tangan berada di ujung hidung. Adapun untuk melakukan sembah kepada sesama manusia, tangan di hulu hati, dengan ujung jari-jari tangan mengarah ke atas. Dikenal juga sembah yang diperuntukan kepada para Bhuta, tangan di hulu hati, tetapi ujung jari-jari tangan mengarah ke bawah. Pada akhir rangkaian persembahyangan dan saat memulai, terdapat sembah dengan tangan kosong dimana sikap cakupan tangan, diletakkan di atas dahi seperti pemujaan ditujukan kehadapan Ida Sang Hyang Widhi.

Salam dengan cakupan tangan di dada yang dilakukan oleh pramusaji, mengikuti kebiasaan persebahyangan di Bali sebagai suatu bentuk penghormatan terhadap tamu yang hendak berkunjung ke restoran mereka. Pada prakteknya di lapangan, pengucapan salam ketika menyambut tamu hanya dilakukan dengan mencakupkan tangan sembari mengucapkan salam sesuai waktu (contohnya: good morning, good afternoon, dst.).

Mengingat di dalam SOP yang digunakan tidak terdapat penggunaaan ungkapan dalam berbahasa Bali, tidak ditemukan penggunaan fungsi-fungsi Bahasa Bali tersebut pada prosedur pelayanan di restoran. Tetapi, adakalanya, pramusaji mengucapkan farewell dengan menyelipkan "suksma" yang diterjemahkan dalam bahasa Indonsia berarti terima kasih. Penggunaan kata" suksma" tersebut, juga terlihat membangun interaksi lainnya antara pengunjung dengan pramusaji. Secara sepintas, tamu akan menanyakan makna serta beberapa kali berlatih mengucapkan kata tersebut. Beberapa pengunjung juga mengatakan akan memperkenalkan kata" suksma" di negaranya, sebagai salah satu 'oleh-oleh' berlibur mereka di Bali.

Pada langkah thanking the guests and farewell: ditemukan keragaman expresi seperti:

1. Matur Suksma (= terima kasih) atau hanya suksma (=bentuk pendek dari matur suksma)/ Thank you for your coming atau Thank you for your dinner,

2. Sampai Jumpa lagi, Thank you for your coming/ Thank you for your dinner.

Expresi 'matur suksma' atau dalam bahasa Indonesia terima kasih, memiliki fungsi yang sama dengan ungkapan terima kasih dalam bahasa Indonesia. Dalam lingkungan Bali, kata ini sangat lazim digunakan dan sering hanya disingkat 'suksma' dengan tanpa mengurangi maknanya.

\section{Pengajaran Bahasa Inggris Tata Hidang di Sekolah Tinggi Pariwisata Bali Internasional}

Pengajaran Bahasa Inggris Tata Hidang di Sekolah Tinggi Pariwisata Bali Internasional (STPBI) mengadopsi pengajaran bahasa Inggris untuk keperluan khusus, English for Specific Purposes, atau yang biasa disingkat ESP.

Materi pengajaran Bahasa Inggris Tata Hidang disesuaikan dengan kebutuhan komunikasi di area restoran. Materi tersebut disusun berdasarkan langkah-langkah pelayanan (sequence of service) di restoran. Mahasiswa dilatih menggunakan ujaranujaran yang dipakai pada langkah-langkah pelayanan tersebut.

Pengajaran Bahasa Inggris dibagi berdasarkan topik. Adapun topik tersebut antara lain: pengenalan jenis-jenis restoran, pengenalan waktu, pengucapan salam, menangani reservasi melalui telepon, mengkonfirmasi pesanan saat kedatangan pengunjung restoran, menawarkan minuman sebelum makanan, mengambil pesanan, menawarkan Hidang penutup, serta menangani pembayaran. Adapun keseluruhan topik termuat pada tabel 1 . 
Tabel 1 :Daftar Topik Pada Mata Kuliah Bahasa Inggris Tata Hidang

\begin{tabular}{|l|l|}
\hline No & Topik \\
\hline 1 & Restaurants \\
\hline 2 & What Time? \\
\hline 3 & Good Morning \\
\hline 4 & Reservations by Phone \\
\hline 5 & Have You Got a Reservation, Please? \\
\hline 6 & Drinks Before Meals \\
\hline 7 & Taking Orders 1: Are you ready to order now? \\
\hline 8 & Taking Orders 2: I recommend today's special. \\
\hline 9 & Taking Orders 3: How would you like it? \\
\hline 10 & Taking Orders 4: Breakfast \\
\hline 11 & Serving Dessert \\
\hline 12 & After Dessert \\
\hline 13 & Room Service \\
\hline 14 & Handling Complaints \\
\hline 15 & Directions and General Services \\
\hline
\end{tabular}

Ketika memasuki langkah-langkah pelayanan di area restoran, terdapat beberapa ungkapan dasar yang diperkenalkan. Adapun keseluruhan ungkapan terangkum dalam tabel 2.

Tabel2 :Ungkapan Bahasa Inggris dalam Pengajaran Bahasa Inggris Tata Hidang

\begin{tabular}{|c|c|c|}
\hline No & Sequence of Service & Ungkapan \\
\hline 1 & welcoming the guest & 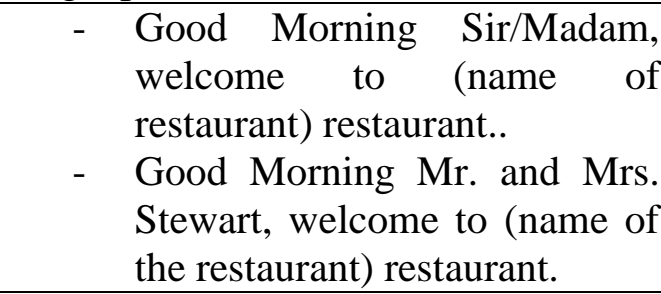 \\
\hline 2 & seating the guest & $\begin{array}{l}\text { - } \quad \text { Have you booked a table? } \\
\text { - } \quad \text { Where would you like to sit? } \\
\text { - } \quad \text { Can you follow me, please? }\end{array}$ \\
\hline 3 & $\begin{array}{l}\text { checking comfort and } \\
\text { seating arrangement }\end{array}$ & - $\quad$ Is everything all right? \\
\hline 4 & serving water & $\begin{array}{l}\text { Excuse me (there is no specific } \\
\text { expression delivered within } \\
\text { this step) }\end{array}$ \\
\hline 5 & presenting тепи & $\begin{array}{l}\text { - Here are the menus. I'll be } \\
\text { back to take your order in a } \\
\text { minute. }\end{array}$ \\
\hline 6 & taking order & $\begin{array}{l}\text { - } \quad \text { Are you ready to order? } \\
\text { - } \quad \text { May I take your order? } \\
\text { - What would you like to start } \\
\text { with? }\end{array}$ \\
\hline
\end{tabular}




\begin{tabular}{|c|c|c|}
\hline & & $\begin{array}{l}\text { - Would you like anything to } \\
\text { drink? } \\
\text { - } \quad \text { Would you like a starter? } \\
\text { - } \quad \text { And what would you like for } \\
\text { your main course? }\end{array}$ \\
\hline 7 & Recommending & $\begin{array}{lll}\text { - Can I recommend you } \\
\text { something? }\end{array}$ \\
\hline 8 & repeating orders & $\begin{array}{l}\text { - } \quad \text { Can I repeat your order? } \\
\text { - So, there will be (listing the } \\
\text { food and drink ordered), } \\
\text { - Is that alright? }\end{array}$ \\
\hline 9 & $\begin{array}{l}\text { presenting food and } \\
\text { drinks }\end{array}$ & $\begin{array}{ll}- & \text { Here's your food, } \\
- & \text { And this is the drink. } \\
- & \text { Enjoy your meal. }\end{array}$ \\
\hline 10 & $\begin{array}{l}\text { checking the guest's } \\
\text { satisfaction }\end{array}$ & $\begin{array}{ll}\text { - } & \text { Is everything all right? } \\
\text { - } & \text { Did you enjoy the meal? }\end{array}$ \\
\hline 11 & offering dessert & $\begin{array}{l}\text { - Would you like something } \\
\text { from our dessert selection? } \\
\text { - Can I interest you in our } \\
\text { dessert menu? }\end{array}$ \\
\hline 12 & clearing and crumbing & $\begin{array}{l}\text { - Would you like me to take } \\
\text { that? }\end{array}$ \\
\hline 13 & presenting the bill & $\begin{array}{l}\text { - I'll get you the bill. } \\
\text { - } \quad \text { Are you paying together? }\end{array}$ \\
\hline 14 & $\begin{array}{l}\text { thanking the guest and } \\
\text { farewell }\end{array}$ & $\begin{array}{l}\text { - Thank you for your meal. } \\
\text { Good bye. } \\
\text { - Thank you for your meal } \\
\text { Sir/Madam. }\end{array}$ \\
\hline
\end{tabular}

Berdasarkan tabel 2, tidak ditemukan penyisipan ungkapan dalam Bahasa Bali pada sequence of service restoran. Pengajaran menekankan keseluruhan ungkapan Bahasa Inggris dan pada prakteknyapun tidak ditemukan saran penggunaan cakupan tangan, ataupun penyisipan kata 'matur suksma'.

Ungkapan dalam menyapa tamu disesuaikan dengan aturan masyarakat berbahasa Inggris, dimana penggunaan gelar sir/madam digunakan untuk menyapa yang tidak

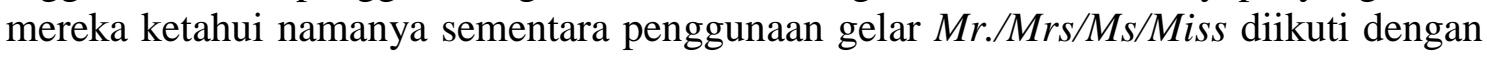
nama lengakap ataupun nama belakang dari tamu tersebut.

Selanjutya, ungkapan ketika berpisah dilakukan dengan mengucapkan :

- Thank you for your visit. Good bye.

- Thank you for your meal, good bye (atau good night, disesuaikan dengan waktu) Tidak ditemukan penyisipan kata 'matur suksma' atau 'suksma' baik di materi ajar maupun pada praktik pengajaran di kelas.

\section{KESIMPULAN DAN IMPLIKASI}

Kearifan lokal Bali sebagai salah satu indikator yang berpengaruh terhadap kepuasan layanan kepada wisatawan, diharapakan dapat terindikasi di setiap aspek 


\section{National Conference of Creative Industry: \\ Sustainable Tourism Industry for Economic Development}

Universitas Bunda Mulia, Jakarta, 5-6 September 2018 e-ISSN No: 2622-7436

layanan. Bahasa Bali adalah juga merupakan penciri budaya di sampingsistem agama dan politik, adat istiadat, perkakas, pakaian, bangunan dan karya seni.

Penggunaan ungkapan-ungkapan bahasa Bali dalam konteks layanan di restoran teridentifikasi saat langkah thanking the guest and farewell, berupa sisipan ungkapan 'matur suksma' atau 'suksma". Ungkapan tersebut diucapkan sebelum berterima kasih dengan ungan berbahasa Inggris. Penggunaan ungkapan terima kasih tersebut, belum ditemukan dalam SOP pelayanan tamu di restoran, tetapi pramusaji melakukan hal tersebut atas respon positif yang diberikan pengunjung.

Interaksi mendalam tercipta ketika pengunjung restoran mulai tertarik terhadap ungkapan 'matur suksma' (=terima kasih) atau 'suksma' (=terima kasih) yang diucapakan saat mereka meninggalkan restoran. Indikasi yang terlihat adalah menanyakan kepada pramusaji perihal makna ungkapan tersebut serta berlatih mengucapkan ungkapan tersebut. Penggunaan ungkapan tersebut, akan lebih diperkuat dan intens lagi ketika diselipkan dalam Standar Operating Procedure layanan di restoran serta disisipkan dalam pengajaran Bahasa Inggris Tata Hidang.

\section{DAFTAR PUSTAKA}

Astina, I Nyoman Gede. 2017. Pengaruh Kualitas Layanan Karyawan Berbasis Kearifan Lokal Bali Terhadap Kepuasan dan Niat Perilaku Loyal Wisatawan Mancanegara Pada Hotel Non Bintang Di Bali. Disertasi. Denpasar : Fakultas Pariwisata Universitas Udayana.

Eraqi, M.I. 2006. Tourism Services Quality(TourServQual) in Egypt. The Viewpoints of External and InternalCustomers. Benchmarking: An InternationalJournal. Vol. 13 No. 4, pp. 469-492.

Kotler, P. and Armstrong, G. 2007. Principles of Marketing.ed.9. 2001. Prentice Hall. Inc. ed. Bahasa Indonesia. Dasar-Dasar Pemasaran. ed.9. 2007. PT Macanan Jaya Cemerlang.

Lestari, Denok.2017. Penggunaan Fungsi-Fungsi Bahasa di Bidang Tata Hidangan Dalam Pembelajaran Keterampilan Berbicara Bahasa Inggris. Disertasi. Denpasar: Fakultas Budaya Universitas Udayana.

Lovelock, C. H. and Wright, L. K. 2007. Manajemen Pemasaran Layanan (Edisi Bahasa Indonesia dari Principles of Service Marketing and Management 2e). PT Macanan Jaya Cemerlang, Jakarta.

Sugiyono. 2010. Metode penelitian Kuantitatif kualitatif \& RND. Bandung: Alfabeta

Wisnumurti, O.A.A.G. 2010. Mengelola Nilai Kearifan Lokal dalam Mewujudkan Kerukunan Umat Beragama. Suatu Tinjauan Empiri-Sosiologis. Yayasan Kesejahteraan Korpri Provinsi Bali. Medion Technocentra. 


\section{National Conference of Creative Industry: \\ Sustainable Tourism Industry for Economic Development}

Universitas Bunda Mulia, Jakarta, 5-6 September 2018 e-ISSN No: 2622-7436

englisch-hilfen.de.At the restaurant (guest - waiter) - Sentences in English. 20 Juli 2018.http://www.englishch-hifen.de/en/words/restaurant.htm.

Denpasar Kota. -. Sejarah Sanur Kauh. 20 Juli 2018. https://sanurkauh.denpasarkota.go.id/

Paduarsana. 26 Mei 2013. Sikap Sembahyang Dalam Hindu. 20 Juli 2018.http://paduarsana.com/2013/05/26/sikap-sembahyang-dalam-hindu/

Prasemix.2018.English expressions that waiters, waitresses, and restaurant staff use.20 juli 2018.https://www.phrasemix.com/collections/english-exoressionthat-waiters-and-restaurant

Sejarah Pantai Kuta.2016. http://sejarahri.com/sejarah-pantai-kuta/

\section{BIODATA}

Penelitian ini dilakukan oleh dua orang peneliti, yaitu, Ni Made Ayu Sulasmini, sebagai peneliti 1 dan I Nyoman Gede Astina sebagai peneliti 2. Peneliti 1 memiliki latar belakang keahlian di bidang pendidikan Bahasa Inggris. Selain sebagai pengajar Bahasa Inggris for Specific Purposes di Kampus STPBI, penulis juga mengasuh mata kuliah Bahasa Inggris Bisnis dan Korespondensi. Keterlibatan penulis di sekolah tinggi pariwisata dan perhotelan, cenderung memberikan kesempatan kepada penulis untuk meneliti bidang Bahasa Inggris dalam aplikasinya di lingkungan perhotelan dan pariwisata. Sementara itu, Penulis kedua merupakan seorang doktor pada bidang kajian Pariwisata. Salah satu penelitian yang dilakukannya, menemukan bahwa terdapat nilainilai kearifan lokal Bali yang mempengaruhi kepuasan serta niat wisatawan untuk melakukan kunjungan kembali. Selain aktif sebagai pengajar Kewirausahaan, Teknik Supervisi serta Operasional Restoran di kampus STPBI, penulis juga aktif di berbagai organisasi Perhotelan dan Pariwisata serta kemasyarakatan. 